JPPUMA: Jurnal Ilmu Pemerintahan dan Sosial Politik UMA(Journal of Governance and Political Social UMA), 8 (2) (2020): 90-98, DOI: https://doi.org/10.31289/ippuma.v8i2.3557

JPPUMA: Jurnal Ilmu Pemerintahan dan Sosial Politik UMA

(Journal of Governance and Political Social UMA)

Available online http://ojs.uma.ac.id/index.php/jppuma

\title{
Evaluation of The Disaster Preparedness School Program at Sekolah Dasar Negeri Baluwarti and Sekolah Dasar Negeri Bangunrejo 1 in Yogyakarta
}

\author{
Afisa * \& Sakir \\ Government Science Study Program, Faculty of Social and Political Sciences \\ Universitas Muhammadiyah Yogyakarta, Indonesia
}

Received: March 05, 2020; Reviewed: May 12, 2020; Accepted: July 23, 2020

\begin{abstract}
This study aims at determining the results of the evaluation of the implementation of the Disaster Preparedness School Program (SSB) as a Disaster Mitigation Step in Yogyakarta City with a case study of SD Negeri Bangunrejo 1 and SD Negeri Baluwarti. The research method used a qualitative evaluative design model CIPP (Context, Input, Process, Product). The results showed that at the context stage, SDN Baluwarti had met the background, targets, organizational structure, facilities and infrastructure, while SDN Bangunrejo 1 had not have a program organizational structure section yet. At the input stage, both of schools did not have specific regulations for the implementation of program in addition SDN Bangunrejo 1 also did not have a special curriculum related to the program. At the process stage, the SSB program was still running well, it is only SDN Bangunrejo 1 focused more on classroom learning while SDN Baluwarti continued to carry out simulations at least once a year. In the product aspect, it was in accordance with the objectives of the SSB program, namely increasing the preparedness of school to disasters.
\end{abstract}

Keywords: Program Evaluation; Disaster Mitigation; Disaster Preparedness School.

How to Cite: Afisa \& Sakir (2020). Evaluation of Disaster Prepared School Program as Disaster Mitigation Measures in Yogyakarta CityJPPUMA: Journal of Government and Social Politics of UMA (Journal of Governance and Political Social UMA), 8 (2) (2020): 90-98

${ }^{*}$ Corresponding author:

E-mail: afsaputriangsa@gmail.com
ISSN 2549-1660 (Print)

ISSN 2550-1305 (Online) 


\section{INTRODUCTION}

Daerah Istimewa Yogyakarta is included in the category of disaster-prone areas in Indonesia. Data and Information on Indonesian Disasters BNPB notes that during 2009-2019, DIY has experienced 522 natural disasters where the most frequent disasters are erosion (129 incidents) and tornadoes (250 incidents) with quite severe impacts ranging from casualties to infrastructure damage (BNPB, 2019). Yogyakarta is in the red zone of a natural disaster-prone area in DIY where the potential for disasters in 20152019 are floods, erosion, and tornadoes / hurricane. Preparedness planning must be fast and efficient by collaborating with a disaster management system adapted to the conditions of the area (Akhmad, Budi, \& Juhadi, 2017) .

Article 44 letter C Act Law Number 24 of 2007 concerning Disaster Management describes disaster mitigation, namely the efforts made to reduce disaster risk for people in disaster-prone areas, one of them is through education. The importance of disaster education through formal education will increase children's resilience to disasters so as to create a strong young generation (Rahma, 2018). For this reason, the Disaster Prepared School Program (SSB) was formed which is based on the Law of the Head of the BNPB Regulation Number 4 of 2012 concerning Guidelines for Implementing Disaster Safe Schools. One example of realizing a basic SSB program is by forming a community consisting of (1) disaster socialization agents (2) first aid agents (3) agents information and communication of post-disaster (Rahman \& Umam, 2018).

DI Yogyakarta Bappeda released data for 2013-2018, there were 81 Disaster Preparedness Schools spread across Sleman Regency (52 schools), Kulon Progo (7 schools), Gunungkidul (8 schools), Bantul (11 schools), and Yogyakarta (3 schools). Disaster Preparedness Schools (SSB) in Yogyakarta were include SD Negeri Bangunrejo 1 and SD Negeri Bangunrejo 2 which were inaugurated since 2015. Meanwhile, SD Negeri Baluwarti began in 2016 (Una, 2016) .

The three schools were chosen because SDN Bangunrejo 1 and 2 are located near the cliffs of the Winongo River which are prone to erosion and floods (Saras, 2015). SDN Baluwarti has the potential for hurricane disasters and is located between dense buildings that commonly occurs an earthquake(Buwana, 2016). Based on this background, the writer intends to do research on "Evaluation of the Disaster Prepared School Program at SDN Baluwarti and SDN Bangunrejo 1, Yogyakarta" to see the extent of the implementation of the SSB program in both schools. This research can also be a recommendation for other schools in implementing disaster preparedness schools.

\section{RESEARCH METHOD}

This research was a qualitative research evaluative design. Sukmadinata in Sukarti (2017) explains that evaluative research is an evaluation procedure in collecting and analyzing data systematically to determine the value or benefit (worth) of a practice (education) based on measurement results or data collection using certain criteria in absolute or relative terms. The program evaluation model used is the CIPP (Context, Input, Process, Product) model developed by Stufflebeam (1976). The research locations were SDN Baluwarti and SDN Bangunrejo 1 Yogyakarta. The number of informants was 17 people. Data collection techniques used were interviews and documentation. Data were analyzed using one of the CAQDAS (ComputerAssisted Qualitative Data Analysis Software) software, namely NVivo 12 plus.

\section{RESULTS AND DISCUSSION Evaluation Context (Context)}

The first stage is context evaluation in the form of efforts to describe and detail the environment of unfilled needs, population and sample served and project objectives (Arikunto, 2014). Therefore the strengths and weaknesses of the program will be identified so that the evaluator can provide the necessary direction for improvement.

Evaluation of the context of the Disaster Preparedness School (SSB) program in Yogyakarta was carried out by knowing how the background of the SSB program to show the reasons for the school being chosen so that it raises the objectives of the program, the organizational structure shows who the stakeholders in program implementation are 
so that there is no overlap, furthermore, authority and infrastructure to support the facilities during SSB. The results of the context indicator can be seen in Figure 1.

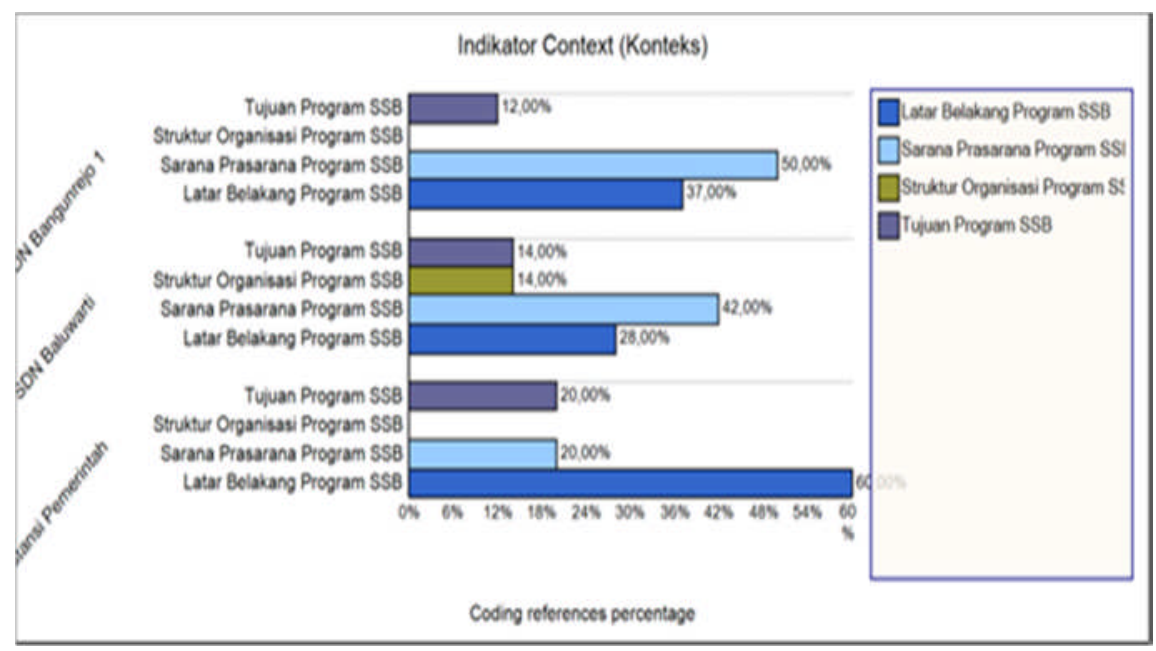

Figure 1. Context Indicator Results (Context)

(Source: processed with Nvivo 12 plus, 20 November 2019)

Based on Figure 1, SDN Baluwarti in implementing the Disaster Preparedness School (SSB) program had met the background of the program, namely its location which was prone to hurricanes and earthquakes, the aim of the program was to minimize the level of disaster risk for school residents, infrastructure, and the organizational structure led directly by the principal. The infrastructure facilities component had the highest points of $42 \%$ because as one of the pilot schools for the SSB program in Yogyakarta, SDN Baluwarti was given fairly complete facilities to be used during simulations and to support learning in class starting from disaster-themed modules, P3K tools, stretchers, Akpar, and warning signs such as meeting points and evacuation routes.

SDN Bangunrejo 1 also had a background that was prone to flooding and erosion, the aim was to prepare residents of the school environment for disasters, facilities and infrastructure that supported the implementation of the SSB program. However, it had not yet have a special organizational structure for the implementation of the SSB program because it was more focused on classroom learning which was adjusted to the ongoing learning theme. The infrastructure component at SDN Bangunrejo 1 was more dominant, thus showing a high point of $50 \%$ due to adequate facilities including disaster- themed modules, first aid kits, stretchers, and Akpar.

The government agency, namely BPBD DIY as the agency that handles the SSB program, was more focused on forming a concept in the form of a program background based on concern for the condition of schools that were destroyed due to the impact of the disaster, so that the aim of the program is that each school has adequate capacity to deal with disaster emergency conditions. Therefore the process of teaching and learning activities continued, as well as providing supporting infrastructure. The organizational structure for implementing the SSB program was handover to each school by involving the principal, teachers, and school committee.

The conclusion was on the indicator context (context) of SSB program in 2 (two) primary schools can be categorized as good where SDN Baluwarti has fulfilled 4 (four) context evaluation indicators. SDN Bangunrejo 1 had a thing that had not been fulfilled, namely the organizational structure of the SSB program development.

\section{Input Evaluation}

The second stage is the evaluation of inputs that can help the researchers to organize decisions, determine alternative sources to be used, plans, strategies, and work procedures to achieve program objectives including human resources, budgetary funds, 
and the necessary regulations. (Darodjat \& Wahyudiana, 2015). Evaluation of inputs to the Disaster Preparedness School (SSB) program in Yogyakarta was carried out by knowing what can support the SSB program in Yogyakarta such as the parties involved, budgets, regulations in running the program, to the learning curriculum used.

The specific learning curriculum on disaster education will serve as a guide during the teaching and learning process in the classroom so that the disaster education delivered can be carried out systematically and clearly. The budget was needed to finance all matters related to activities in the implementation of the SSB program. Specific regulations related to program implementation will serve as guidelines in running the program so that it is in accordance with the initial objectives of its formation. The parties involved refer to external parties in supporting and running the program. This indicator shows the things that support the implementation of the SSB program in Yogyakarta. The results on the Input indicator can be seen in Figure 2.

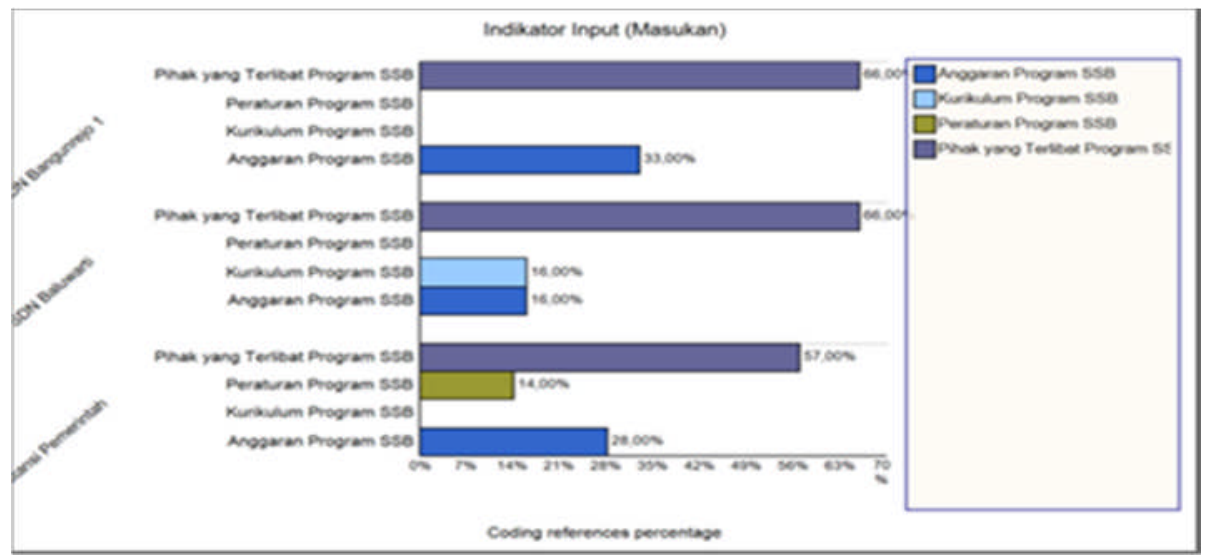

Picture. 2.Input Indicator Results (Input)

(Source: processed with Nvivo 12 plus, 20 November 2019)

Based on Figure 2, SDN Baluwarti was quite good at implementing the Disaster Preparedness School (SSB) program which had fulfilled 3 of the 4 existing sections, except for the special regulations for implementing the SSB program. External parties involved in the implementation of the SSB program when it was inaugurated were from the Puskesmas, Police, and LimNas.

Now the SSB program was independent so the only parties involved were internal schools, although there were large-scale simulations every 2-3 years involving external parties. Regarding the budget, SDN Baluwarti used BOS funds in program implementation and there was already a curriculum and syllabus on subjects in grades I-VI regarding the SSB program.

SDN Bangunrejo 1 had fulfilled 2 of the 4 existing assessment sections, namely the external parties involved and the program budget. It means that SDN Bangunrejo 1 can be categorized as sufficient in implementing the SSB program. During the simulation during the inauguration in 2015, it involved external parties such as the Police, National LimNas and Puskesmas. After the inauguration there was no more simulation so that external parties were not involved again. The budget for implementing the SSB program at SDN Bangunrejo 1 was allocated from BOS funds. There was no specific regulations and curricula related to program implementation, but the lesson plan did exist. Disaster education was usually associated with a learning theme book in class.

There were many government agencies involved during the preparation until the inauguration of the SSB program, including the Yogyakarta Education Office, Indonesian Army, Police, NGOs, Health Clinic, Indonesian Red Cross, and the Health Office. Their involvement such as the Yogyakarta Education Office assisting in the preparation of the disaster education curriculum, the Army / Police were involved in rehearsals and simulations of activities, NGOs were involved in the preparation of contingency plan, and health 
clinic / Indonesian Red Cross / Health Office were involved in providing PPGD (Emergency First Aid Training ).

The budget from preparation to inauguration was funded entirely by BPBD DIY in the form of infrastructure, consumption, transportation, and so on. There were several regulations that were used as a legal basis for implementing the SSB program, including Regulation of Minister of Education and Culture Number 72 of 2013 concerning the Implementation of Special Service Education and Regulation of the Head of BNPB number 4 of 2012 concerning Guidelines for Implementing Disaster Safe Schools.

It can be concluded that the SSB program input indicators in 2 (two) primary schools can be categorized as sufficient, seen from 4 sections of the discussion, namely the parties involved, the program curriculum, special regulations related to the program, and the budget in program implementation. However, there were things that had not been fulfilled, such as the curriculum and special regulations related to the SSB program at SDN Bangunrejo 1 and SDN Baluwarti also did not have specific regulations related to the SSB program.

\section{Process Evaluation}

The third stage is the evaluation of the process (process) to see how far the activities had been carried out according to plan and control whether a program had provided feedback (Arikunto, 2014). The process evaluation in the SSB program in Yogyakarta was carried out by knowing what activities were carried out in the program, who is the responsibleman, and when the activities will be completed so that it was known to what extent the Disaster Preparedness School (SSB) program was running in Yogyakarta.

The type of activity explained the activities carried out in carrying out the SSB program so that it was in accordance with the initial plan of formation. The people in charge of the program would act as a leader during activities so that there was no overlapping of authority. The existence of a target time for program implementation would be used as a reference for calculating the time from the start the program was formed to its completion. The results on the process indicator can be seen in Figure 3.

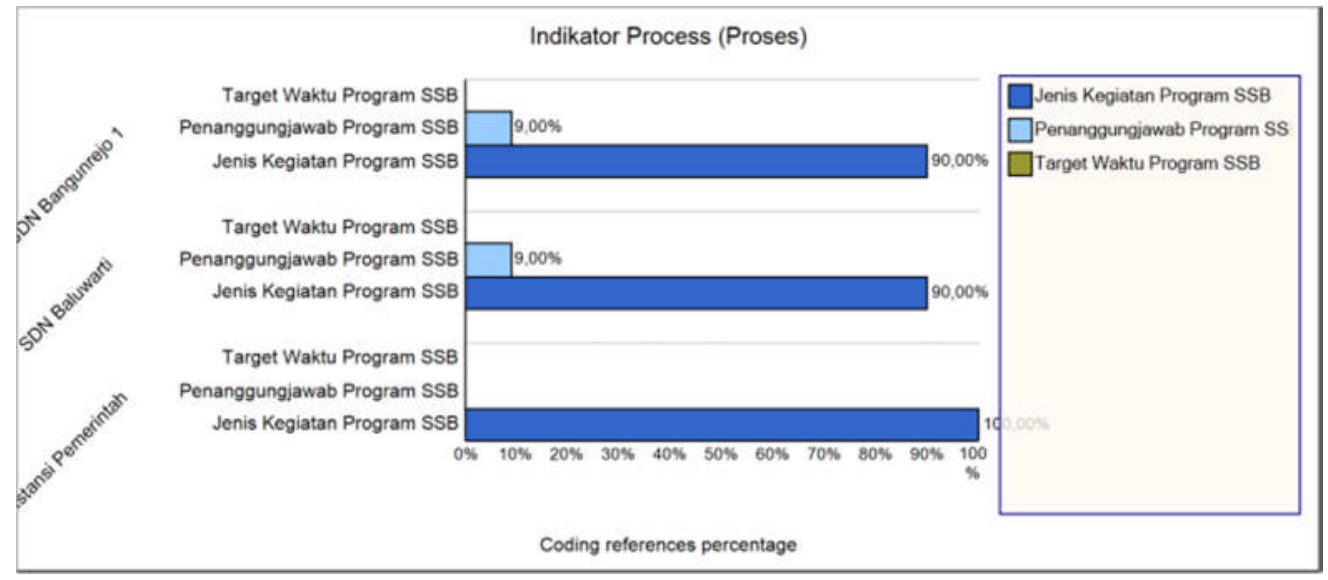

Figure 3.Process Indicator Results (Process)

(Source: processed with Nvivo 12 plus, 20 November 2019)

Based on Figure 3, SDN Baluwarti and SDN Bangunrejo 1 both had the same score. The types of activities were the same, from preparation to inauguration. The results of the interview stated that in 2018 at SDN Baluwarti, students of the Sarjanawiyata Tamansiswa University (UST) majoring in Elementary School Teacher had ever held a program that invited the teachers at schools who implemented the SSB program to write interesting and simple story books about disasters in order to be easily understood by students. The activity started with the socialization of disaster mitigation, how to write children's stories, the practice of writing children's stories containing disaster mitigation, the publishing process and printing to be distributed to schools that implementing the SSB program adapted with the potential disasters. 
The activity simulation at SDN Bangunrejo 1 was not as active as SDN Baluwarti which did it once a year. SDN Bangunrejo 1 had not yet conducted another simulation after the inauguration in 2015. The socialization carried out by SDN Baluwarti includes socialization with the guardians of students every new school year to training / simulations with local residents and related parties (Apriyanti, 2019). The headmaster was directly responsible for implementing the SSB program at SDN Baluwarti and SDN Bangunrejo 1.

BPBD DIY explained during the interview how the process of establishing the SSB program at SDN Baluwarti and SDN Bangunrejo 1 which was initiated by the socialization of vulnerabilities in schools including what needed to be prepared for 2 days that gathered the teachers, the committees and the surrounding community. The first Technical Guidance was the compiler of the Contingency Plan to synergize 3 elements (government, society and business world), teachers and committees with the main target of parents because children were a susceptible group to disasters. The organizers aimed to train the teachers and local communities to be able to make plans dealing with disasters where the results were documents that describe who is involved, what to do, the infrastructure, where, and how to deal with disasters.

Contingency Plan will become Operation Plan when a disaster occurs to prevent the confusion over disasters and also the overlapping responsibilities as well as to assess existing risks, how to reduce risks, constraints, and available resources. The results can be in the form of evacuation maps, owned infrastructure, and school disaster preparedness teams. There was a curriculum development index that integrated disaster risk management materials, the result was Lesson Plan or Syllabus which contains disaster mainstreaming so that a culture of disaster preparedness can emerge. Contingency Plan, which has been prepared beforehand, was made a scenario, then finally rehearsals and simulations were held. The simulation scenario needed to be done repeatedly, until it was formalized (launching) as SSB.
The conclusion on the process indicators for the SSB program at SDN Baluwarti and Bangunrejo 1 can be categorized as good when seen from the 3 sections of the discussion, namely the target implementation time, the people in charge of program implementation, and the types of activity. There are 2 parts that have been fulfilled, namely the people in charge of program implementation and types of activities. The target time for the implementation of the SSB program at two schools had not been fulfilled because BPBD DIY wanted the program to be continuous by being carried out independently by each school.

\section{Product Evaluation (Results)}

The fourth stage is the evaluation of the results (product) in the form of an assessment carried out to measure the level of success in achieving the program objectives that have been planned before. The results of the evaluation will determine whether the program still needs to be continued, improved, or even stopped (Darodjat \& Wahyudiana, 2015). Evaluation of the results of the Disaster Preparedness School (SSB) program in Yogyakarta was to assess the success of the program in achieving the achievements that had been designed and observed the impact that occured as evidence of the ongoing process of the program to produce a new policy whether this program needs to be improved in new ways so that it is more effective.

There are 7 main problems in implementing school-based Disaster Risk Reduction (DRR) including policies on DRR education in Indonesia that are not well understood in the school environment, insufficient access to DRR education materials, inadequate teacher capacity and platform, partnerships between schools and the stakeholders that are not synchronized, the minimum budget and children's participation (Amri, Bird, Ronan, Haynes, \& Towers, 2017). The availability of resources to mobilize participation, training and staff development, and an understanding of the objectives and outcomes of their participation are factors influencing children's participation in DRR(Muzenda-Mudavanhu, 2016). The results on the product indicator (results) can be seen in Figure 4. 



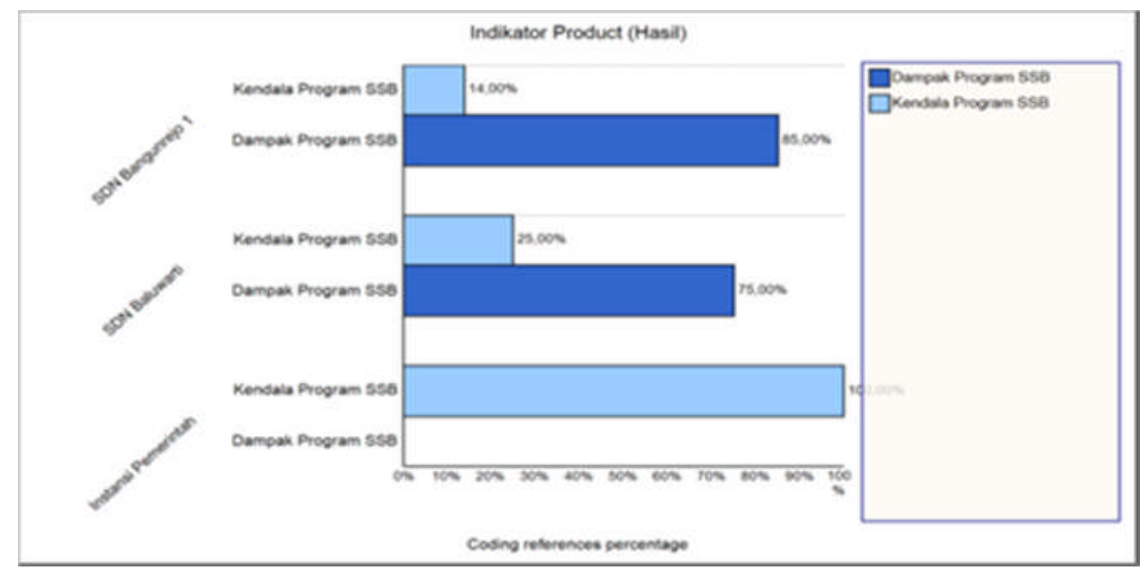

Figure 4.Product Indicator Results (Results)

(Source: processed with Nvivo 12 plus, 20 November 2019)

Based on Figure 4, the impact perceived by residents of the school environment and the surrounding community on the implementation of the SSB program at SDN Baluwarti and SDN Bangunrejo 1 is at a value above $70 \%$ which means satisfactory. It indicates that the SSB program in both schools was considered effective in order to improve disaster education, with several obstacles that must be fixed by SDN Baluwarti, SDN Bangunrejo 1, and BPBD DIY.

SDN Baluwarti had several obstacles such as changes to the Technical Guidelines for the BOS funds which then had an impact on the accountability report (LPJ) for SSB activities, concerns about the metal readiness of students when a real disaster occured, and the density of school activities which made it difficult for teachers to find time to implement the program.

The obstacle faced by SDN Bangunrejo 1 was the limited time in which SDN Bangunrejo 1 had to share a place with SDN Bangunrejo 2 which was still in the renovation stage so that each subject is reduced by 10 minutes. BPBD DIY had more problems with lack of coordination with the government, limited human resources, and low public awareness of disasters.

It can be concluded that the indicators for the evaluation of the results (product) of the SSB program at two schools in terms of the impact that were generated can be categorized as very good and successful according to program objectives. It is due to the impact on program targets such as students, parents, and residents around the school environment is very positive, namely increased preparedness in facing disasters, especially for students. There are several obstacles that must be fixed including: 1) all subjects taught according to the curriculum must be integrated with disaster preparedness, 2) teachers must include disaster preparedness values in various media and learning materials, 3 ) still limited props / media and existing facilities in disaster prepared schools(Siti \& Ardian, 2018).

\section{CONCLUSION}

Based on the results and discussion of research evaluation of the Disaster Preparedness School (SSB) program in the city of Yogyakarta with a case study of SD Negeri Baluwarti and SD Negeri Bangunrejo 1 with CIPP model from Stufflebeam (1976), namely Context (context), Input (input), Process (process), and Product (result), it can be concluded that; 1) context evaluation can be categorized as going well where SDN Baluwarti has fulfilled all the components of the assessment, while SDN Bangunrejo 1 had not fulfilled the special organizational structure component for implementing the SSB program yet. 2) input evaluation can be categorized as sufficient because SDN Baluwarti had not yet have special regulations for the SSB program and SDN Bangunrejo 1 also had not have specific regulations and curricula yet. 3) the evaluation process can be categorized as good because both schools are still running the SSB program, but SDN Bangunrejo 1 was more focused on learning planning education in class. 4) product evaluation can be categorized as very good because the residents of the 
school environment feel the positive impact of the SSB program, namely the increasing disaster education in the school environment.

\section{REFERENCES}

Akhmad, E. F., Budi, S. A., \& Juhadi. (2017). Edu Geography SEMARANG. 5(3), 86-94.

Amri, A., Bird, D. K., Ronan, K., Haynes, K., \& Towers, B. (2017). Disaster risk reduction education in Indonesia: Challenges and recommendations for scaling up. Natural Hazards and Earth System Sciences, 17(4), 595-612. https://doi.org/10.5194/nhess17-595-2017

Apriyanti, W. (2019). Implementasi Program Mitigasi Bencana Melalui. Jurnal Kebijakan Pendidikan, 8 (2), 123-133.

Arikunto, S. \& S. A. J. (2014). Evaluasi Program Pendidikan. Jakarta: PT. Bumi Aksara.

Badan Nasional Penanggulangan Bencana. (2012). Pedoman Penerapan Sekolah/Madrasah Aman dari Bencana. 3, 84. https://doi.org/10.1038/labinvest.3780307

BNPB. (2019). Data Kebencaan di Indonesia. Retrieved from http://dibi.bnpb.go.id/databencanaB

Buwana, A. G. (2016). Jenjang SD Jadi Sasaran Mitigasi Bencana. RadarJogja. Retrieved from

https://radarjogja.jawapos.com/2016/04/0

7/jenjang-sd-jadi-sasaran-mitigasibencana/

Darodjat \& Wahyudiana. (2015). Model Evaluasi Program. Islamadina, XIV(1-28).

Muzenda-Mudavanhu, C. (2016). Jamba-Journal of Disaster Risk Studies Affiliation: A review of children's participation in disaster risk reduction. Jamba - Journal of Disaster Risk Studies, $\quad 8(1), \quad 1-16$. https://doi.org/10.4102/jamba

Rahma, A. (2018). Implementasi Program Pengurangan Risiko Bencana(PRB) Melalui Pendidikan Formal. Jurnal VARIDIKA, 30(1), 1-11.

https://doi.org/10.23917/varidika.v30i1.65 37

Rahman, F., \& Umam, Q. (2018). Sena Sakti ( Sekolah Bencana; Siaga , Aksi dan Mitigasi ). Jurnal Ilmiah Ilmu Sosial, 4(1), 6-11.

Saras, B. D. (2015). MITIGASI BENCANA: SDN Bangunrejo Jadi Sekolah Siaga Bencana. Solopos.Com. Retrieved from https://www.solopos.com/mitigasibencana-sdn-bangunrejo-jadi-sekolahsiaga-bencana-578807

Siti, A., \& Ardian, A. (2018). Pembuatan Buku Cerita Anak Bermuatan Penanggulangan. Abdi, 3(2), 88-92.

Una. (2016). SD Baluwarti Jadi Sekolah Siaga Bencana. TribunJogja.Com. Retrieved from https://jogja.tribunnews.com/2016/04/06 /sd-baluwarti-jadi-sekolah-siaga-bencana

Zahro, Z. R., Andriningrum, H., Sari, E. P., \& Gunawan, I. (2014). Sekolah Siaga Bencana: Kajian Evaluatif Kesiapsiagaan Sekolah Menghadapi Bencana. Seminar Nasional Pendidikan, Fakultas Ilmu Pendidikan Universitas Negeri Malang. Sinergitas Keluarga, Sekolah Dan Masyarakat Dalam Penguatan Pendidikan Karakter, 511-519.

Regulation of the Head of BNPB number 4 of 2012 concerning Guidelines for the Implementation of Disaster Safe Schools / Madrasah. 